\title{
Conditions and factors of humus formation in soils of mountain and foothill
}

\author{
Maruf Tashkuziev ${ }^{1 *}$ and Nilufar Shadieva ${ }^{2}$ \\ ${ }^{1}$ Research Institute of Soil Sciences and Agrochemistry, Kamarniso str., Tashkent, 100174 \\ Uzbekistan \\ ${ }^{2}$ Tashkent State Agrarian University, University str., 2, Tashkent province, 100174 Uzbekistan
}

\begin{abstract}
On the basis of information on the climatic factor, the intensity of humus formation in the soil was estimated. It was revealed that as the transition from the plain to the foothills and low mountains due to changes in atmospheric precipitation and hydrothermal regime, the period of biological activity (PBA) of the soil increases from the plain to the mountains. The balance of annual radiation in the foothill plain is 47 $\mathrm{kcal} / \mathrm{cm}^{2}$, in the high-mountain belt $-53 \mathrm{kcal} / \mathrm{cm}^{2}$. As the transition from the plain to the mountainous part of the relief, an increase in soil PBA was revealed and, in accordance with this, the content and reserves of humus, as well as labile humic substances in the humus composition, increase. By the type of humus, light gray soils are humate-fulvate and fulvate; typical, dark gray soils and mountain brown soils, fulvate-humate; light brown meadow-steppe soils, and humate. It also provides information on the energy reserves of humus for the considered soils. The correlations between the indicators of PBA and humus for horizon "A" in the studied soils were calculated.
\end{abstract}

\section{Introduction}

The most complex organic compound in the composition of the soil is soil humus, its origin; its formation is associated with long-term biochemical processes [1]. Also, soil humus is such a substance that differs sharply from the parent rock, which contains compounds that are not found in the parent rock. Humus is the main indicator of soil fertility, an important morphological and genetic indicator of the soil; it is considered an energy source and reserves of plant nutrients $[2,3]$.

It is known that the accumulation of humus in the soil and its quality depends on many factors, such as climatic conditions, terrain, the quantity and quality of decomposed plant biomass, the chemical composition of the soil, its water-physical properties, and thermal regime $[4,5]$.

In the conditions of the Republic of Uzbekistan, depending on the natural climatic conditions, the biomass of plant residues in the zone of dry steppes (deserts) in one hectare is formed in the amount of 0.8-1.5 tons, in the zone of gray soils - about 4-6 tons [6]. On irrigated sierozem soil, alfalfa accumulates up to 12-14 tons of organic matter. Part of these

* Corresponding author: nilufarshadieva@yandex.com 
organic residues are in a state of incomplete decomposition, slightly altered form, and the other part, as a result of dying off and the decomposition process, passes into a black, highly altered mass with a complex composition, a complex organic compound, which passes into humus and is absorbed by the mineral part of the soil [7-9].

Humus is a source of energy in the soil, since it absorbs the passing solar energy, as well as the energy released from the soil, as a result of biochemical and redox processes [10]. At the same time, humus is a vital source of plant nutrition and biological value of many nutrients, especially nitrogen and carbon dioxide [10, 11]. As a result of humus mineralization, which is a product of dying off, decomposition and humification of organic residues, containing calcium, magnesium, potassium, ammonia in the soil are converted into a new form - into compounds that are more accessible. Also, humus helps to improve the physical, mechanical, chemical, biochemical and other properties of the soil and increase its fertility [12].

It should be noted that a number of works have been devoted to the study of the content and composition of humus in plains and foothills of rainfed soils in the republic by now [13]. The questions of the influence of the anthropogenic factor, erosion phenomena, indicators of fertility of various subtypes of sierozem and mountain brown soils are sanctified in them.

However, the mechanism of the formation of humic substances under the influence of individual soil-forming factors - climate, relief and vegetation cover, taking into account the regional characteristics of the territory in relation to the main types, subtypes of foothill and mountain soils - has not been sufficiently studied [1-4, 14].

In this article, we will dwell on the issue of the humus state and humus formation under the influence of individual soil formation factors in the mountain and foothill soils of the northern spurs of the Turkestan ridge, subject to varying degrees of erosion, which are widespread in the Sanzar river basin.

\section{Materials and methods}

This paper used comparative-geographical and comparative chemical-analytical research methods, including profile and morphological methods. Analyzes of the chemical composition of the soil were carried out according to the generally accepted methods described in the manuals of EV Arinushkina [15] and Agrochemical methods of soil research [16]. The total humus was determined by the method of IV Tyurin, the fractionalgroup composition of humus was determined by the method of IV Tyurin modified by IV Ponomareva and TA Plotnikova [17]. The period of biological activity of the soil (PBA), the energy reserve of humus was calculated according to DS Orlov and LA Grishina [18]. The biomass of the surface part of plants in $1 \mathrm{~m}^{2}$ of area was determined according to $\mathrm{N}$. Savvinov and N. Pankova [19].

For soils common in foothill and mountainous regions, an increase in the amount of atmospheric precipitation is characteristic, as a result of this, the capacity and types of vegetation cover, the content of humus, the thickness of the humus horizon increase, and the processes of humus formation are noticeably accelerated.

Climatic conditions and terrain are one of the important factors in humus formation. With regard to the agrolandscape of the studied region, based on the analysis of materials from the Hydrometeorological Center of Uzbekistan [20], we compiled Table 1, which shows the influence of two main factors of climate and relief, directly affecting humus formation. 
Table 1. Main indicators of climate and terrain influencing humus formation

\begin{tabular}{|c|c|c|c|c|}
\hline Indicators & $\begin{array}{c}\text { Foothill } \\
\text { plains }\end{array}$ & $\begin{array}{c}\text { Foothill } \\
\text { adyrs }\end{array}$ & Hills & Mountains \\
\hline $\begin{array}{c}\text { Annual radiation balance } \\
\text { (kcal/cm2) }\end{array}$ & 47 & 48 & 50 & 53 \\
\hline Duration of frost-free days & 196 & 190 & 177 & 170 \\
\hline $\begin{array}{c}\text { The total amount of } \\
\text { temperature is above 100C }\end{array}$ & 2.547 & 2.547 & 2.547 & 2.547 \\
\hline Duration of 12 C0>t & 234 & 232 & 230 & 225 \\
\hline Duration of 10 $\mathrm{C}^{0}>\mathrm{t}$ & 217 & 208 & 203 & 200 \\
\hline Average annual, $\mathrm{t}^{0}$ & 15.0 & 13.8 & 11.2 & 10.9 \\
\hline Temperature of hottest days & $+41.1^{\circ}$ & $+40^{\circ}$ & +35.4 & +35.0 \\
\hline Temperature of coldest days & -13.2 & -15.4 & -17.6 & -17.9 \\
\hline $\begin{array}{c}\text { Sum of annual precipitation, } \\
\mathrm{mm}\end{array}$ & 382.0 & 396.2 & 432.8 & 500 \\
\hline
\end{tabular}

The most important climatic parameters in humus formation change depending on the relief conditions, namely, an increase above sea level, the radiation balance of the studied region increases. The radiation balance in the foothill plains is $47 \mathrm{kcal} / \mathrm{cm}^{2}$, in the high mountain regions $-53 \mathrm{kcal} / \mathrm{cm}^{2}$. The duration of frost-free days is gradually decreasing from the foothill plains to the high mountain regions (by 196-170 days). The total temperature above $10{ }^{\circ} \mathrm{C}$ in this region is $2,547{ }^{\circ} \mathrm{C}$. The duration of days with temperatures above $12{ }^{\circ} \mathrm{C}$ in the foothill plains is 234 days, in the middle and high mountain areas it is 230-225 days. The average annual temperature is $15.0-11.2{ }^{\circ} \mathrm{C}$, the temperature of the hottest month of the year in the foothill plains is $+41.1{ }^{\circ} \mathrm{C}$, in the foothill adyrs $+40{ }^{0} \mathrm{C}$, in the mid- and high-mountainous regions it is about $35.4-35.0{ }^{0} \mathrm{C}$. Air temperatures on the coldest days range from $-13.2{ }^{\circ} \mathrm{C}$ to $-17.6{ }^{\circ} \mathrm{C}$. Annual precipitation is $382-500 \mathrm{~mm}$.

\section{Results and discussion}

In different soil and climatic zones, differences in atmospheric precipitation, hydrothermal conditions, and the period of biological activity (PBA) have a significant effect on the humus content and its qualitative composition. Under conditions of vertical zoning in humus formation, the value of the hydrothermal factor is significant, and as it rises from the plains to the mountains, atmospheric precipitation, hydrothermal conditions and soil PBA change.

In the $60-80$ s of the last century, Russian scientists carried out a number of studies showing the relationship between the humus state of the soil and climate indicators. Based on their results, MM Kononova put forward the idea that the effectiveness of the soil PBA is a function of moisture and temperature [21].

In this respect, the PBA was calculated for all the main soils of the Russian Federation. In soils with moderate climatic conditions and northern zones, despite the sufficient amount of moisture, due to the lack of heat, PBA mainly depends on the soil temperature. Starting from the soils of the tundra zone to chernozems, the PBA varies from 40-50 days to 160170 days. In the dark chestnut soils of Dagestan, these indicators are 190-194 days and, depending on this, the $\mathrm{Cg}$ : Cfc ratio is 2.2-2.4 [10-13].

The amount of total carbon in light gray soils distributed in the foothill plains is $0.62 \%$ or $1.05 \%$ of humus, in typical gray soils distributed in the foothill adyrs $0.92 \%$ or $1.58 \%$ of humus, in dark gray soils and carbonate, typical mountainous brown soils common in low mountains is, respectively, $1.01 \%$ or $1.74 \%$ of humus, $1.11 \%$ or $1.91 \%$ of humus and $1.54 \%$ or $2.65 \%$ of humus, and in mountain brown soils, weakly leached and light brown 
meadow-steppe soils widespread in the highlands is, respectively, $1.73 \%$ or $2.98 \%$ of humus and $2.05 \%$ or $3.53 \%$ of humus.

According to the proposed system of indicators of the humus state [9], to the proposed new system in the considered soils in the $0-30 \mathrm{~cm}$ layer, the ratio $\mathrm{Cgc}$ : Cfc is characterized by the following indicators: in light, typical and dark gray soils from 0.75 to 0.90 , humate fulvate $(0.75-1.0)$; in the southern exposure of carbonate mountain brown soils 0.93 humate-fulvate type, typical and weakly leached mountain brown and light brown meadowsteppe soils 1.02-1.12 - fulvate-humate (1.0-1.25). In the northern expositions of alpine soils, these indicators are $1.18 ; 1.21 ; 1.21 ; 1.30$ refers to the fulvate-humate type (1.0-1.25), and 1.30 , which refers to the humate type (1.25-1.5).

From the data presented, it is revealed that in different soil-climatic zones, differences in the period of biological activity (PBA), in atmospheric precipitation, hydrothermal conditions have a huge impact on the amount and quality of humus. The short duration of this indicator (73-79 days) in rainfed light and typical sierozems is mainly characterized by low moisture content. In rainfed dark gray soils (90 days) and mountain brown, light-brown meadow-steppe soils, with the highest PBA duration (95-100 days), the best conditions are created for the accumulation of humic acids, which are valuable in humus formation. The level of humification in the studied soils of the mountain zones is 2.1-2.4 times higher than in the soils of the sierozem belt of the foothill plains.

The degree of humification of organic matter (Cgc:Ctot $\mathrm{x} 100 \%)$ in the soils of the highlands is much higher than in the foothill plains and adyrs. According to the indicators of the humus state, in accordance with the classification $[4,14]$ and refined by us in highmountain light brown meadow-steppe soils, its value is the highest - 39.9\%, in three subtypes of mountain brown soils it is $31.5-32.5 \%$, in dark gray soils $-27.6 \%$, typical gray soils $25.7 \%$, light gray soils $-18.9 \%$ and varies from high $(30-40 \%)$ to weak $(10-20 \%)$ levels. This indicator exceeds 1.6-2.1 times in high-mountainous and mountainous soils in comparison with the soils of the foothill plains.

It is known that the humus of the soil and the energy reserve of humus are important in the processes taking place in the soil and the stability of the biosphere. VA Kovda refers to the humus layer of the soil as a separate energy crust of our planet - i.e. considers it a humosphere. According to his suggestion, in dry matter accumulated in the soil in $1 \mathrm{~g}$ of plant residue, it is formed in the amount of $17-21 \mathrm{~kJ}$ of energy [8].

The highest energy reserve among the studied soils was noted in light brown meadowsteppe soils, where it is $844.7-870.7 \mathrm{million} \mathrm{kcal} / \mathrm{ha}$. It was revealed that among the studied soils of the northern exposure, the energy reserve is 1.1-1.5 times higher than that of the soils of the southern exposure.

The smallest amount of hydrolyzable substances Cgk + Cfk falls on rainfed light gray soils and accounts for $44 \%$ of the total carbon. Its amount in typical gray soils and dark gray soils of the plain and adyr part increases to $58.2 \%$, and in low-mountain and highmountain brown and light-brown meadow-steppe soils is within $57.6-70.5 \%$.

There is a high correlation between the depth of humification (the ratio of Cgc: $\mathrm{Cfc}$ ) and the period of biological activity of the soil. At the same time, the highest relationship $r=$ 0.91 was determined between PBA and indicators of the depth of humification (the ratio of $\mathrm{Cgc:} \mathrm{Cfc})$. This indicates that PBA indicators play an important role in the humification process. The lowest correlation $r=0.14-0.10$ was observed between PBA and fulvic acids. There is a correlation between humic acids and the level of humification of organic matter and indicators of PBA, equal to $r=0.87-0.76$. There is a high correlation between GK-2 and GK-3 and climate indicators $r=0.73-0.88$.

When comparing mountain soils with sierozem soils formed in the foothill zone, in sierozem in connection with the hydrothermal regime, in which plant residues rapidly decompose, mineralize and a smaller amount of humus is formed. However, in comparison 
with mountain brown soils, sierozem soils are distinguished by the enrichment of humus with nitrogen. According to the indicators of the enrichment of humus with nitrogen, the considered soils belong to the high and above the average level.

As it rises above sea level, the degree of humification of organic matter increases from low to high.

It was established that in the considered rainfed gray soils and three subtypes of mountain brown soils, as well as light brown meadow-steppe soils, as the rise from sea level, the increase in PBA and, in accordance with this, an increase in the content of humus, especially its labile form and the energy reserve of humus. It was also revealed that these indicators depend on the exposure and slope of common soils. In accordance with this, soils that are widespread in the northern exposure of the slope, regardless of the type of soil, noticeably differ from the soils of the southern exposure in the content of humus, its reserves, the better expression of the thickness of the humus horizon, as well as better vegetation cover.

The peculiarities of mountain and foothill soils, which are widespread, are, as they rise up, the amount of atmospheric precipitation increases. As a result, changes occur in the vegetation cover, its species, humus content, and the thickness of the humus layer, which contributes to the acceleration of the process of humus formation. It is known that the mountain conditions formed on uneven terrain in the protection of the soil cover play a significant role of annual, perennial green plants, shrubs, semi-shrubs and forest plantations. They regulate the flow of rainfall and play an essential role in preventing the washing out of the top fertile soil layer. The soils of the investigated area, widespread at the lower and middle elevations of the area, are widely used in rainfed agriculture and horticulture.

The region we are considering for the botanical and geographical zoning of Uzbekistan is distinguished by its distribution and vegetation in the mountainous and foothill regions into 8 districts and 23 districts, and in the plains into 8 districts and 15 districts $[2,5]$. According to this, in terms of botanical and geographic zoning, the research carried out by us, the region covers the Kuhitangsky district, the Northern Turkestan and Morguzar districts.

More than 1000 plant species are spread in the mountainous and foothill areas of the Turkestan ridge. The flora changes as it rises above sea level, depending on the degree of slope of the slopes, soil cover, climatic conditions. During the period of our research, the following world of vegetation was covered: adyrs (lower adyr, upper adyr), mountains (lower mountains, high mountains), and pastures (lower pastures, upper pastures).

The studies provide a geobotanical characteristic of the vegetation of the region under consideration. At the same time, the association of the type of plants, their average height, and tiers were characterized, and samples of plants were taken to take into account the coverage of the soil surface, the corresponding measurement and registration work was carried out.

In the studied region, in accordance with the typical difference in soils, the formation of vegetation also changes. Sierozem soils are distributed from the upper part of the plains, inclusively to the mid-altitude mountains, covering all sloping plains. These soils are formed in arid climatic conditions with the participation of ephemeral-ephemeral plant formations. As it rises from the sloping foothill plains to the upper part of the low mountains, the arid properties of the climate decrease and the species of late vegetating plants increase the amount of humus and organic matter in the soil increases.

In light gray soils from widespread ephemeroids, the rank-phomis formation of Carex pachystylis, Poabulbosa in warm and humid spring months develops densely and forms sods. In the summer they die off. Among ephemeroids, Papaver pavonium, Delphinium persicum, Alyssum desertorum, Malsomlia turcestanica, and others are widespread. 
In typical gray soils, plants growing in summer are combined with ephemeralephemeral plants. These are certain species of umbellates (Saligeria allioides, $S$. Transcaspica), flomis (Phlomis thapsoides, Ph.bucharica) zusinia (Cousinia reanosa), colored butterfly (Psoralea drupacea) and others.

In dark gray soils, the height and density of plants increases even more. The main plants are Agrorurum triuchophorum, Hordeum bulboum; tall herbaceous plants Ferula Jaeschkeana sovina, Codonocephalum, and Prahgos pabularia grow together. Wheatgrass is the main background and in this regard, this region is considered as dry steppe wheatgrass-tall vegetation.

In calcareous mountain brown soils, mainly herbaceous semi-shrubs Elytrigia trichophora, Pimpinella anisum, Mentha piperita, Rosa canina, R. kokanica grow in the dry outskirts there are rare spruce forests, low woody and lodging species of plants.

In typical mountain brown soils, shrub and rarely spruce vegetation (juniper forests) grow. Elytrigia trichophora, Pimpinella anisum and large grassy Prangos pobularia Ferula grow in open treeless places formed from sparsely spruce vegetation.

In weakly leached mountain brown soils, the vegetation is represented by a diverse mountain-forest association; the lower zone is represented by shrub-herbaceous species Elytrigia trichophora, Pimpinella anisum, Mentha piperita, Rosa canina, and R. kokanica. Juniper forests are widespread on the outskirts of the mountains, with tree species of vegetation.

In light brown meadow-steppe soils, mesophytic rare forest and meadow-steppe plant associations are widespread.

Table 2. Geobotanical characteristics of the studied soils.

\begin{tabular}{|c|c|c|c|c|c|c|c|}
\hline \multirow[b]{2}{*}{ Indicators } & \multicolumn{3}{|c|}{$\begin{array}{c}\text { Sierozem/ } \\
\text { geobotanical association }\end{array}$} & \multicolumn{3}{|c|}{$\begin{array}{c}\text { Mountain Brown } \\
\text { Soil/Geobotanical Association }\end{array}$} & \multirow[b]{2}{*}{ 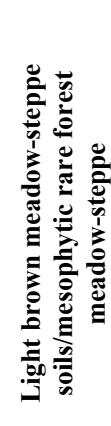 } \\
\hline & 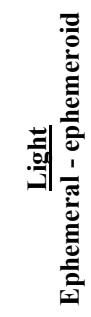 & 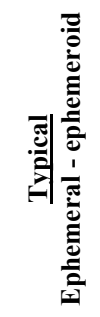 & 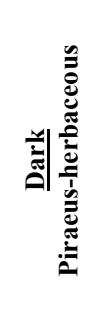 & 泀| & 昰毵 & 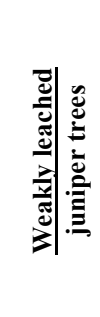 & \\
\hline $\begin{array}{c}\text { Vegetation cover, } \\
\%\end{array}$ & $60-70$ & $70-75$ & $75-80$ & $80-85$ & $85-90$ & $90-95$ & $90-95$ \\
\hline $\begin{array}{l}\text { Average height of } \\
\text { vegetation, cm }\end{array}$ & $35-45$ & $40-50$ & $50-80$ & $55-85$ & $70-90$ & $70-90$ & $55-100$ \\
\hline $\begin{array}{c}\text { Aboveground } \\
\text { phytomass, } \mathrm{q} / \mathrm{ha}\end{array}$ & 148.1 & 162.8 & 258.1 & 340.8 & 484.0 & 596.8 & 1072.0 \\
\hline $\begin{array}{c}\text { Underground } \\
\text { phytomass, q/ha }\end{array}$ & 317.9 & 363.1 & 598.8 & 752.6 & 837.6 & 1337.6 & 2241.6 \\
\hline $\begin{array}{l}\text { underground/above } \\
\text { ground }\end{array}$ & 2.1 & 2.2 & 2.3 & 2.2 & 1.7 & 2.2 & 2.1 \\
\hline $\begin{array}{c}\text { Total stock of } \\
\text { phytomass, } \mathrm{q} / \mathrm{ha}\end{array}$ & 466 & 525.9 & 856.9 & 1093.4 & 1321.6 & 1934.4 & 3313.6 \\
\hline $\begin{array}{l}\text { Humus reserve, } \\
\text { tons/ha }\end{array}$ & 74.25 & 127.1 & 141.1 & 144.5 & 175.9 & 175.9 & 249.9 \\
\hline
\end{tabular}

In relation to the object of research, the existing distribution of vertical zoning of light, typical, dark gray soils, carbonate, typical and weakly leached mountain brown soils, as 
well as light brown meadow-steppe soils, we studied vegetation, analyzed their geobotanical characteristics (Table 2).

According to the data obtained, the studied soils belong to the following geobotanical associations: light and typical sierozem to ephemeral-ephemeroid, dark gray wheatgrassherbaceous soils, calcareous mountain-brown mountain xerophytic soils, typical mountainbrown forest-shrub soils, weakly leached to archa-brown soils and soils light brown meadow-steppe soils mesophytic rarely forest and meadow-steppe. The existing distribution of soils from the foothill plains to the alpine zone, the vegetation cover increases from $60-70 \%$ to $90-95 \%$. Also, as it rises from the plains to the mountains, the average height of the vegetation cover increases from $34-45 \mathrm{~cm}$ to $55-100 \mathrm{~cm}$.

In accordance with this, as the vertical zoning increases, an increase in the amount of aboveground and underground biomass is noted. Namely, its lowest amount is noted in rainfed light gray soils, here the aboveground mass in $1 \mathrm{~m}^{2}$ of $0-20 \mathrm{~cm}$ soil layer is 148.1 $\mathrm{g} / \mathrm{cm}^{2}$, in typical gray soils this indicator is $162.8 \mathrm{~g} / \mathrm{cm}^{2}$; dark gray soils $258.1 \mathrm{~g} / \mathrm{cm}^{2}$; in 3 subtypes of mountain brown soils - 276.0-803.6 g/ $\mathrm{cm}^{2}$; light brown meadow-steppe soils $1,072 \mathrm{~g} / \mathrm{cm}^{2}$. Accumulated in 2.0-2.6 times more underground biomass compared to aboveground. This can be explained by the following: the above-ground mass is eaten in large quantities by animals or by humanity is mowed for food.

\section{Conclusions}

In humus formation in soils, climatic factors and terrain are important. Hydrothermal processes, their change on the surface of the earth, depending on the relief, received their evidence. Also, the results obtained reveal the differences in the period of biological activity (PBA) of dependence in different soil-climatic zones on atmospheric precipitation, hydrothermal conditions and the value of this indicator for the content and composition of soil humus.

It was revealed, in the studied soils, an increase in indicators of the type of humus and PBA from light gray soils to light brown meadow-steppe soils. If in light gray soils precipitation is a lowering factor, in light brown meadow-steppe soils it is temperature.

The highest energy reserves in the studied soils are found in light-brown meadowsteppe soils, where it is $844.7 \mathrm{million} \mathrm{kcal} / \mathrm{ha}$. It was determined that among the studied soils of the northern exposure, the energy reserves in humus are 1.1-1.5 times higher than that of the soils of the northern exposure.

The total stock of phytomass in light gray soils is 466 quintals/ha and increases in light brown meadow-steppe soils to 3,313.6 quintals/ha. In accordance with the increase in phytomass in these soils, an increase in the content of total humus is noted.

\section{References}

1. M. Gates, Ecology, 46, 1-14 (1965)

2. B. Labaz, B. Galka, A. Bogacz, J. Waroszewski, C. Kabala, Geoderma, 230, 265-273 (2014)

3. M.I. Dergacheva, E.I. Kovaleva, N.N. Ryabova, Eurasian Soil Science, 40(12), 12641269 (2007)

4. O. Zaiets, R.M. Poch, Geoderma, 272, 83-92 (2016)

5. N. Bernier, J.F. Ponge, Soil Biology and Biochemistry, 26(2), 183-220 (1994)

6. E.V. Abakumov, Eurasian soil science, 43(5), 499-508 (2010) 
7. M.M. Tashkuziev, N.I. Shadieva, Humic substances in the biosphere, 2, 671-677 (2010)

8. T.H. DeLuca, G.H. Aplet, Frontiers in Ecology and the Environment, 6(1), 18-24 (2008)

9. J.L. Retzer, Journal of Soil Science, 7(1), 22-32 (1956)

10. O. Bojko, C. Kabala, Catena, 149, 209-220 (2017)

11. I.V. Kotsenko, E.V. Abakumov, Eurasian Soil Science, 51(12), 1411-1418 (2018)

12. I.V. Kotsenko, Eurasian Soil Science, 50(5), 515-525 (2017)

13. Y.N. Krasnoshchekov, Eurasian Soil Science, 54(1), 25-37 (2021)

14. A.A. Shpedt, Y.V. Aksenova, IOP Conference Series: Earth and Environmental Science, 624(1), 012233 (2021)

15. E.V. Arinushkina, Soil Chemical Analysis Guide, 487 (MSU Press, Moscow, 1970)

16. M. Karimov, N. Namozov, B. Teshaboev, E3S Web of Conferences, 244, 02025 (2021)

17. V.V. Ponamoreva, T.A. Plotnikova, Humus and soil formation, 110-204 (1980)

18. D.S. Orlov, L.A. Grishina, Workshop on humus chemistry, 272 (MSU Press, Moscow, 1982)

19. N.I. Savvinov, N.A. Pankova, Root system of vegetation of virgin areas of the TransVolga steppes and a new method of its study, 171 (1972)

20. N. Namozov, M. Tursinbaev, I. Yuldoshev, S. Yuldasheva, E3S Web of Conferences, 244, 02007 (2021)

21. M.M. Kononova, Soil organic matter, 313 (1963) 